\title{
Is Technology in Our Classrooms? \\ EFL Teachers' Beliefs and Engagement with Technology in the Classroom
}

\author{
Devrim Hol (Corresponding author) \\ Pamukkale University, Turkey \\ E-mail: devrimpau@gmail.com
}

Irem Aydın

Pamukkale University, Turkey

E-mail: aaydnirm@gmail.com

Received: July 6, 2020 Accepted: August 12, 2020 Published: August 22, 2020

doi:10.5296/jei.v6i2.17326 URL: https://doi.org/10.5296/jei.v6i2.17326

\begin{abstract}
This study aims to investigate the beliefs of Turkish EFL teachers about implementing digital technology in the classroom and the underlying factors which affect their beliefs. Quantitative research design was selected and online Beliefs Questionnaire was used for data collection. The participants of the study consisted of 563 Turkish in-service EFL teachers working at state schools, private schools or colleges in various parts of Turkey. Descriptive statistics and correlation analysis were performed to determine whether the participants' four categorized beliefs about the use of digital technology (i.e. importance, use, expertise, and context) interrelated with each other, and if any of the participants' demographic and background factors (i.e. age, gender, level of education, years of teaching experience) predicted the reported beliefs. The results indicated that teachers shared positive views on the use of digital technology in EFL classrooms in terms of importance, use, expertise, and context. It was also found that gender, age and teaching experience did not create any significant change on teachers' beliefs.
\end{abstract}

Keywords: digital technology, English language teaching, teacher education, foreign language teaching 


\section{Introduction}

"If we teach today's students as we taught yesterday's, we rob them of tomorrow."

(John Dewey as cited in Murthy, 2020).

The past decade has witnessed a rapid development in the field of educational technology with the increasing role of technology in every part of human life. With no surprise, education, which increases the value and the quality of the human life, has also started to be affected by these technological developments (Zengin \& Aksu, 2017). Since, as Prensky (2001) stated, "today's students are no longer the people our educational system was designed to teach". Computer games, emails, the Internet, cell phones and instant messaging services have become an essential part of their lives and it is widely accepted that digital tools and internet is a vital tool that enhances learning. Today's students, with the denotation of Prensky (2001), "digital natives", are considered, it is understood that integrating technology into the classroom is of vital importance to raise the effectiveness of the teaching-learning process (Mirzajani, Rosnaini, Ayub, \& Wong, 2016). As mentioned, technology is improving at a dazzling and continuous pace, but in this movement and change, students are final users, and that is teachers who are anticipated to integrate technology into their practices in learning and teaching environment, and they are the key utilizer of technology implementation in education (Basal, 2015; Galvis, 2012; Judson, 2006). In modern classrooms, it is seen that using technology takes a great place in learning a foreign language and language teachers have begun to use some common digital media and resources such as videos, PowerPoint presentations and Web 2.0 tools because they are aware of the advantages of the technology use in the classroom in regard to traditional pedagogy (Fauzi, Damayanti \& Ilahi, 2017; Galvis, 2012). In addition, as Lin (2009) expressed, teaching foreign language learners with the computer technology and the Internet assists not only learning the language actively and cooperatively but also probing their own learning processes positively. Consequently, the implementation of the digital technology in foreign language teaching has become on the march (Chung, 2014) and this issue has attracted many of the researchers' attention (Almekhlafi \& Almeqdadi, 2010); thus, led researchers to conduct studies about why some teachers prefer using digital technology in foreign language teaching and others do not. At this point, it is noteworthy to understand and assess teachers' beliefs and the underlying factors for the integration of technology in language teaching (Uluay, Nibat, \& Arıkan, 2019).

\subsection{Literature Review}

As the tutoring practices of the teacher in the classroom are directly affected by the teacher's beliefs (Kagan, 1992), it is necessary here to clarify exactly what is meant by teacher beliefs. According to a description provided by Kagan (1992), "Teacher belief is defined broadly as tacit, often unconsciously held assumptions about students, classrooms, and the academic material to be taught" (p. 65). This definition is close to that of Pajares (1992) who identifies teachers' beliefs as "attitudes of teachers about education-about schooling, teaching, learning, and students." (p. 316). What is more, Pajares (1992) alleged that teachers have educational beliefs about distinct themes and areas along with general beliefs and their educational beliefs help their decision making process about integrating technology to the 
curriculum (Galvis, 2012). As was pointed out in the introduction, teachers' beliefs have been investigated as a substantial domain of quest for 15 years in language teaching (Phipps \& Borg, 2009). Therefore, in the related literature, there are many studies analyzing teachers' beliefs about implementing digital technology in language teaching.

In her small scale study, Lam (2000) aimed to investigate 10 L2 teachers' perceptions about using technology for teaching language and the factors affecting these perceptions by applying a questionnaire and an oral interview with the participants. According to the findings, all the participants found using technology as beneficial for their daily life and they regarded technology-based teaching as an additional instrument assisting their teaching practices. Moreover, it was understood that the background features of the L2 teachers such as the number of teaching experience years, prior technological training, gender or age had no impact on teachers' technology use in language teaching.

Yang and Huang (2007) sought to examine the current trends and patterns of 332 high school English teachers' concerns and teaching behavior related to technology integration in Taiwanese context. The analysis of the data collected from Integrating technology into English instruction Belief scale (ITEIBS) and other four scales assessing concerns, behaviors and the school environment indicated that English teachers had positive beliefs about implementing technology for teaching English and thus, these beliefs supported their teaching behaviors. In addition, there were positive correlation between technology-mediated teaching activities and the factors affecting technology implementation such as technological training or school environment. However, teaching experience factor showed a different result. Inexperienced teachers or teachers having less than 5 years' experience strived more to integrate technology in language teaching.

In their comprehensive investigation, Rahimi and Yadollahi (2011) aimed to evaluate 248 EFL teachers' degree of Information and Communication Technology (ICT) use in teaching English and determine the effect of EFL teachers' personal and technology-related features in ICT use in Iran. According to the results, technology was generally utilized for teaching listening and speaking by the teachers. What is more it was found that there was inverse correlation between ICT use and teachers' age, years of teaching experience and computer anxiety, and also ICT use was noticeably associated with academic credentials, computer ownership, computer literacy, and use whereas attitude and gender had no impact on ICT use.

Yunus (2007) conducted a research to explore ESL technical school teachers' current use of ICT, the factors impressing their ICT use and insights of their skills in ICT in Malaysia. Findings demonstrated that teachers did not prefer to utilize ICT in teaching English. However, most of the teachers took a positive attitude about exploiting ICT in language teaching and almost half of the teachers regarded themselves as competent/very competent in teaching practices while vast majority of the teachers rated themselves as competent/very competent in using ICT for personal purposes. In the study, lack of access and lack of training to use ICT were found as two main troubles which were experienced by the teachers.

In their qualitative design study, Sağlam and Sert (2012) investigated 9 in-service English language teachers' perceptions about technology implementation in classroom in regards to 
its usefulness, the pros and cons and incorporation into teaching practice. The study found that the participants had positive opinions about the ameliorating function of implementing educational technology in teaching. However, lack of confidence and skills of the teachers in utilizing the technology uncovered the need for ICT training.

Chung (2014) aimed to explore 35 pre-service and in-service ESL teachers' beliefs concerning implementation of digital technology in teaching process and the origins of those beliefs. The analysis of the data collected from beliefs' questionnaire and interviews indicated that the participants mostly had favorable attitudes about the use of digital technology in ESL classrooms; they were content with their skills in using digital technology and aware of the importance in teaching English. In addition, it was understood that there was a strong relationship between their beliefs and their technological training, technological proficiency and context. However, the beliefs of the teachers varied in terms of teaching experience and age factor.

In his study, Karakaya (2010) examined 87 in-service teachers' attitudes about computer technology and evaluated the degree of their technology use in language teaching. According to the findings, although teachers held positive attitudes toward the use of technology, they were not able to put implementation of technology into practice in language education. When examining the factors affecting teachers' attitudes, it was found that while age and gender had no significant effect on teachers' attitudes about using technology, the degrees teachers hold and teaching experience showed strong positive correlation with the attitudes toward using ICT.

In 2017, Chaaban and Ellili-Cherif analyzed the characteristics and perceptions of Qatari EFL teachers' technology integration into classrooms. A survey delving into technology availability and support, teachers' value and self-efficacy beliefs, obstacles to technology integration, and formal technology preparation was answered by 263 teachers and the results showed that technology integration in language teaching is moving slowly in spite of high investments made in teacher education and accessing to technology. Besides, technology accessibility, teachers' perceptions of importance and formal instruction are directly proportionate to the level of technology integration.

In their cutting edge paper of 2017, Liu, Lin, and Zhang attempted to determine the types of pedagogical beliefs held by Chinese foreign language teachers and the impact on the teachers' attitudes about technology acceptance in the classroom context. The data collected from 202 EFL teachers via a questionnaire extracting teachers' pedagogical beliefs, perceptions of ICT's usefulness and ease of use, attitudes toward it, and intention to use it were assessed using path analysis. According to the results, it was found that the constructivist-oriented beliefs of teachers had a substantial positive effect on three of Technology Acceptance Model (TAM), which was the revised model used in this study, (perceived usefulness, perceived ease of use and attitude toward use) while teachers' transmissive pedagogical beliefs did not impress their attitudes toward information and communication technology (ICT).

Tondeur, Braak, Ertmer, and Ottenbreit-Leftwich (2017) conducted a review study to comprehend deeply connect between teachers' pedagogical beliefs and their technology use 
in their teaching by assessing the results of the 14 elected studies. The findings were stated with five synthesis statements: "describing (1) the bi-directional relationship between pedagogical beliefs and technology use, (2) teachers' beliefs as perceived barriers, (3) the association between specific beliefs with types of technology use, (4) the role of beliefs in professional development, and (5) the importance of the school context." (p. 555). Consequently, it was concluded that teachers' pedagogical beliefs should be placed a particular importance in teacher education programs where how to use technology properly for tutoring purposes is taught.

Ding, Ottenbreit-Leftwich, Lu, and Glazewski (2019) who aimed to investigate the connection between 12 EFL teachers' content-specific pedagogical beliefs and their technology integration practices implementing a multiple-case study found a general correlation between EFL teachers' beliefs and their practices, and although PowerPoint is the mostly used technological tool by EFL teachers, their intended use for language teaching practices varies teacher by teacher.

Several other studies have also produced estimates of using digital technology in language teaching, but especially in Turkish context, there is still insufficient evidence and data for understanding the beliefs of EFL/ESL teachers. As can be concluded from the previous studies, the implementation of digital technology for language teaching seems as a common and important concern that although EFL teachers hold positive beliefs, the use of digital technology is affected by lots of various factors. In this sense, it would be interesting to know what is happening in Turkey and what Turkish in-service teachers believe about the use of digital technology in teaching, and it was hoped that the findings would yield fruitful findings for all the stakeholders ranging from the participants, EFL teachers in this context, to the governmental organizations. All in all, present study aims to investigate the beliefs of Turkish EFL teachers about implementing digital technology in the classroom and the underlying factors which affect their beliefs. This paper seeks to address the following research questions:

(1) What are the beliefs of EFL teachers about the use of digital technology in the classroom?

(2) What are the factors affecting the beliefs of EFL teachers?

\section{Method}

\subsection{Research Design}

This study seeks answers to find out Turkish EFL teachers' beliefs about implementing digital technology in the classroom and the underlying factors affecting their beliefs. For this study, we handled quantitative research to gather the relevant data as it helps to collect data from a large number of people using instruments with preset questions and responses in a short time in an effective way (Creswell, 2002). Therefore, a survey research design was chosen because surveys are the best way to identify important beliefs and attitudes of individuals (Creswell, 2002). 


\subsection{Instrument and Data Collection}

Data were collected by using adapted version of Beliefs Questionnaire developed and used by Chung (2014). The questionnaire comprises of two parts; the first part includes demographic information about the participants and the second one includes 31 Likert scale belief items. Background information part aims to gather information about teachers' current situation, level of education, years of teaching experience, level of learners that they are currently teaching, age and gender. In the second part, the participants are asked to evaluate their experiences with technology in their personal life and in teaching English by self-assessing their proficiency(i.e., unfamiliar, newcomer, beginner, intermediate, advanced, and expert), the purposes of digital technology-related activities (i.e., instructional, communicative, informative, organizational, creative, recreational, evaluative, and expansive), and frequency of using digital technology for each purpose (i.e., daily, weekly, monthly, rarely, and never). Lastly, the participants provide information about any technology-related training they had completed giving details of duration, purpose, and location. The second part consisted of 31 Close-ended beliefs statements all rated on a five-point Likert-scale. The questionnaire was prepared via Google forms and administered online. It was shared on Facebook groups related to English teachers. The responses given the questionnaire were extracted from Google Drive and converted to an Excel file. The data were then transferred to the Statistical Package for Social Science (SPSS) Version 21 for analyses.

\subsection{Participants}

The participants of this study were Turkish in-service EFL teachers working at state schools, private schools or collages from various parts of Turkey. The initial sample consisted of 643 in-service English teachers, 80 of them did not complete the questionnaire, gave inconsistent answers or gave the same answers for all questions, and they were excluded from the main study. The table below illustrates the demographic information of the teachers. Table 1 shows that $76.4 \%$ (430) of the participants are female and 23\% (133) of them are male. $74.4 \%$ (419) of the participants have bachelor's degree, $13.5 \%$ of the participants (76) have M.A degree and $12.1 \%$ (68) have PhD degree. According to the years of teaching experience, $20.6 \%$ (116) are between 1-5 years, 27\% (152) are between 6-10 years, 29.1\% (164) are between 11-15 years, $14.2 \%$ (80) had a service life of 16-20 years and 9.1\% (51) had a service life of 21 years or more. $9.4 \%$ (53) of the participants were between the ages of $20-25,17.2 \%$ (97) were in the 26-30 age range, $34.1 \%$ (192) were in the $31-35$ age range, $22.6 \%$ (127) were between $36-40$ years old, $8.9 \%$ (50) were between $41-45$ years, and finally $7.8 \%$ (44) were aged 46 and over. 
Table 1. The demographic information of the teachers

\begin{tabular}{|c|c|c|c|}
\hline Demographic Information & & Frequency & Percent \\
\hline \multirow{3}{*}{ Gender } & Female & 430 & 76.4 \\
\hline & Male & 133 & 23.6 \\
\hline & Total & 563 & 100.0 \\
\hline \multirow{4}{*}{ Level of education } & Bachelor & 419 & 74.4 \\
\hline & MA Degree & 76 & 13.5 \\
\hline & $\mathrm{PhD}$ & 68 & 12.1 \\
\hline & Total & 563 & 100.0 \\
\hline \multirow{6}{*}{ Years of teaching experience } & $1-5$ & 116 & 20.6 \\
\hline & $6-10$ & 152 & 27.0 \\
\hline & $11-15$ & 164 & 29.1 \\
\hline & $16-20$ & 80 & 14.2 \\
\hline & $21+$ & 51 & 9.1 \\
\hline & Total & 563 & 100.0 \\
\hline \multirow{7}{*}{ Age } & $20-25$ & 53 & 9.4 \\
\hline & $26-30$ & 97 & 17.2 \\
\hline & $31-35$ & 192 & 34.1 \\
\hline & $36-40$ & 127 & 22.6 \\
\hline & $41-45$ & 50 & 8.9 \\
\hline & $46+$ & 44 & 7.8 \\
\hline & Total & 563 & 100.0 \\
\hline
\end{tabular}

\section{Results}

Descriptive statistics and correlation analysis were performed to determine if the participants' four categorized beliefs about the use of digital technology (i.e., importance, use, expertise, and context) interrelated with each other, and if any of the participants' background factors (i.e., age, gender, level of education, years of teaching experience, self-rated proficiencies of using digital technology as a teacher and in personal life, and technology-related training experience) predicted the reported beliefs. The results of the study were explained by answering each research question respectively.

3.1 Research Question 1. What Are the Beliefs of EFL Teachers About the Use of Digital Technology in the Classroom?

Table 2 presents the results gathered from the quantitative analysis of the 31 beliefs statements according to four belief sub dimensions. As can be seen from the table (below), the mean score of importance dimension is $(M=4.34)$, and in this dimension while item 1 "I 
find digital technology useful in enhancing my performance as a teacher in the classroom" has the highest mean score $(M=4.72)$, item 6 "The use of digital technology in the classroom limits my abilities as a teacher" has the lowest mean score $(M=3.51)$. In use dimension, the overall mean score is $(M=4.48)$. Item 13 "The use of digital technology makes lessons enjoyable for my students" is of highest mean score $(M=4.62)$ whereas item 12 "I am willing to make digital technology regular feature in my teaching" has the lowest mean score $(M=4.29)$. When the expertise dimension is examined, it is seen that the overall mean score is $(M=4.05)$. Besides, Item 16 "I can use digital technology to collect information from a variety of resources" is the most agreed statement $(M=4.50)$ and item 22 "When I use digital technology in the classroom, I need help from other staff" is the least agreed statement $(M=$ 3.33 ) in this dimension. Lastly, the mean score of the context dimension is the lowest among the other three dimensions $(M=3.74)$. The highest mean score belongs to Item 24 "I have access to digital technology in my classroom" $(M=4.08)$ and the lowest one belongs to item 31 "The teachers and staff in my school actively use digital technology" $(M=3.74)$.

Table 2. The mean scores of beliefs statements

\begin{tabular}{|c|c|c|c|}
\hline No. & Statements & Mean & $\begin{array}{l}\text { Std. } \\
\text { Deviation }\end{array}$ \\
\hline 1 & I find digital technology useful in enhancing my performance as a teacher in the classroom. & 4.72 & 0.50 \\
\hline 2 & $\begin{array}{l}\text { I find digital technology useful in improving my students' language skills (i.e. reading. writing. listening. and } \\
\text { speaking) when I teach. }\end{array}$ & 4.70 & 0.49 \\
\hline 3 & As a teacher. I am enthusiastic about using digital technology in the classroom & 4.54 & 0.64 \\
\hline 4 & I feel it is important for students to be enthusiastic about using digital technology in the classroom & 4.34 & 0.72 \\
\hline 5 & I feel it is important for students to actively participate in activities using digital technology. & 4.39 & 0.68 \\
\hline 6 & The use of digital technology in the classroom limits my abilities as a teacher & 3.51 & 1.41 \\
\hline 7 & I am willing to learn more about digital technology & 4.48 & 0.70 \\
\hline 8 & I feel that it is important to use digital technology in the classroom & 4.46 & 0.69 \\
\hline 9 & I feel that the use of digital technology interrupts the normal classroom activities & 3.64 & 1.33 \\
\hline 10 & $\begin{array}{l}\text { I feel that digital technology is beneficial in motivating my students to participate in the classroom } \\
\text { activities. }\end{array}$ & 4.58 & 0.65 \\
\hline & Importance & 4.34 & 0.48 \\
\hline 11 & I provide my students with opportunities to use digital technology. & 4.40 & 0.65 \\
\hline 12 & I am willing to make digital technology regular feature in my teaching & 4.29 & 0.73 \\
\hline 13 & The use of digital technology makes lessons enjoyable for my students. & 4.62 & 0.61 \\
\hline \multirow[t]{2}{*}{14} & The use of digital technology lets my students have fun in the classroom. & 4.60 & 0.63 \\
\hline & Use & 4.48 & 0.51 \\
\hline 15 & I would describe myself as an early adaptor of digital technology compared to my fellow teachers & 4.03 & 0.93 \\
\hline
\end{tabular}




\begin{tabular}{|c|c|c|c|}
\hline 16 & I can use digital technology to collect information from a variety of resources & 4.50 & 0.66 \\
\hline 17 & I can use digital technology to facilitate academic learning & 4.35 & 0.71 \\
\hline 18 & When I use digital technology in the classroom. I understand clearly how to use it & 4.38 & 0.66 \\
\hline 19 & I can troubleshoot common problems when using digital technology & 3.65 & 1.04 \\
\hline 20 & I can choose digital technology based on its appropriateness to specific tasks in the classroom & 4.23 & 0.70 \\
\hline 21 & I can use digital technology to communicate with students & 3.97 & 0.96 \\
\hline 22 & When I use digital technology in the classroom. I need help from other staff. & 3.33 & 1.30 \\
\hline \multirow[t]{2}{*}{23} & I am confident in using all kinds of digital technology available in my classroom & 4.05 & 0.88 \\
\hline & Expertise & 4.05 & 0.51 \\
\hline 24 & I have access to digital technology in my classroom & 4.08 & 1.00 \\
\hline 25 & $\begin{array}{l}\text { I am satisfied with technical infrastructure in my school (e.g. internet connection. digital technology } \\
\text { equipment). }\end{array}$ & 3.65 & 1.19 \\
\hline 26 & $\begin{array}{l}\text { I am satisfied with resources available in my school regarding the use of digital technology in learning and } \\
\text { teaching language }\end{array}$ & 3.60 & 1.17 \\
\hline 27 & I am encouraged to attend in educational programs regarding digital technology. & 3.83 & 1.08 \\
\hline 28 & Students are encouraged to use digital technology in the school & 3.86 & 1.02 \\
\hline 29 & The teachers and staff in my school are enthusiastic about using digital technology & 3.63 & 1.00 \\
\hline 30 & The teachers and staff in my school are encouraged to use digital technology & 3.66 & 1.03 \\
\hline \multirow[t]{2}{*}{31} & The teachers and staff in my school actively use digital technology. & 3.56 & 1.02 \\
\hline & Context & 3.74 & 0.82 \\
\hline
\end{tabular}

Table 3. The sub dimensions of the scale

\begin{tabular}{|l|l|l|l|l|l|}
\hline Sub dimensions of the Scale & $\mathrm{N}$ & Mean & Std. Deviation & Skewness & Kurtosis \\
\hline Importance & 563 & 4.34 & 0.48 & -0.43 & -0.34 \\
\hline Use & 563 & 4.48 & 0.51 & -1.03 & 1.19 \\
\hline Expertise & 563 & 4.05 & 0.51 & -0.23 & 0.11 \\
\hline Context & 563 & 3.74 & 0.82 & -0.68 & 0.55 \\
\hline
\end{tabular}

When Table 3 was examined, it was found that Skewness (-.68; -1.03) and Kurtosis (-.34; 1.19) values were within the limit values within the scope of univariate normality. According to Shiel and Cartwright (2015), Skewness and Kurtosis values between 2 and -2 are considered sufficient for normal distribution. In this context, it can be said that the data show normal distribution. The mean scores of digital technology beliefs scale sub dimensions are: importance $(M=4.34, \mathrm{SD}=0.48)$, use $(M=4.48, \mathrm{SD}=0.51)$, expertise $(M=4.05, \mathrm{SD}=$ $0.51)$, context $(M=3.74, \mathrm{SD}=0.82)$. The highest mean score is in the use dimension and the 
lowest in the dimension of use of teachers is context. The results, as shown in Table 1, indicate that they have mostly positive beliefs on digital technology.

Table 4. Correlation between four categorized beliefs' sub dimensions

\begin{tabular}{|l|l|l|l|l|l|}
\hline & Dimensions & 1 & 2 & 3 & 4 \\
\hline 1 & Importance & - & & & \\
\hline 2 & Use & $.739^{* *}$ & - & & \\
\hline 3 & Expertise & $.533^{* *}$ & $.629^{* *}$ & - & \\
\hline 4 & Context & $.133^{* *}$ & $.424^{* *}$ & $.420^{* *}$ & - \\
\hline
\end{tabular}

As Table 4 shows, it is seen that there is a high level significant correlation between importance and use $(\mathrm{r}=.739)$, medium level significant correlation between importance and expertise $(\mathrm{r}=.53)$, low level significant correlation between importance and context $(\mathrm{r}=.13)$. Additionally, there is medium level significant correlation between use and expertise $(r=.62)$; use and context $(\mathrm{r}=.424)$ and expertise and context $(\mathrm{r}=.420)$.

3.2 Research Question 2. What Are the Factors Affecting the Beliefs of EFL Teachers?

\subsubsection{Gender}

Table 5. Analysis of beliefs on digital technology by gender

\begin{tabular}{|l|l|l|l|l|l|l|l|}
\hline Sub dimensions & Gender & $\mathrm{N}$ & Mean & Std. Deviation & $\mathrm{t}$ & $\mathrm{df}$ & Sig. \\
\hline \multirow{3}{*}{ Importance } & Female & 430 & 4.35 & .482 & 1.256 & 561 & .531 \\
\cline { 2 - 9 } & Male & 133 & 4.29 & .480 & & & \\
\hline \multirow{3}{*}{ Use } & Female & 430 & 4.46 & .527 & -1.222 & 561 & .508 \\
\cline { 2 - 9 } & Male & 133 & 4.52 & .463 & & & \\
\hline \multirow{3}{*}{ Cxpertise } & Female & 430 & 4.01 & .501 & -3.056 & 561 & .356 \\
\cline { 2 - 9 } & Male & 133 & 4.17 & .510 & & & \\
\hline \multirow{2}{*}{ Context } & Female & 430 & 3.66 & .815 & -3.592 & 561 & .440 \\
\cline { 2 - 9 } & Male & 133 & 3.95 & .784 & & & \\
\hline
\end{tabular}

T-test was used in order to compare teachers' beliefs on digital technology with gender. When the table 5 examined, it was seen that sub dimensions (importance $[\mathrm{t}(1.256)=.531, \mathrm{p}>$ $0.05]$, use $[\mathrm{t}(-1.222=.508, \mathrm{p}>0.05]$, expertise $[\mathrm{t}(-3.056)=.356 \mathrm{p}>0.05]$ and context $[\mathrm{t}(-3.592)=.440, \mathrm{p}>0.05])$ did not show a statistically significant difference in terms of gender. 


\subsubsection{Age}

Table 6 . The analysis of importance dimension by age

\begin{tabular}{|l|l|l|l|l|l|l|l|l|l|}
\hline Age & N & Mean & Std. Deviation & Source of Variance & Sum of Squares & df & Mean Square & F & Sig. \\
\hline $20-25$ & 53 & 4.35 & 0.45 & Between Groups & .457 & 5 & .091 & .391 & .855 \\
\hline $26-30$ & 97 & 4.37 & 0.50 & & & & & & \\
\hline $31-35$ & 192 & 4.32 & 0.49 & & & & & & \\
\hline $36-40$ & 127 & 4.30 & 0.47 & Within Groups & 130.061 & 557 & .234 & & \\
\hline $41-45$ & 50 & 4.39 & 0.47 & & & & & & \\
\hline $46+$ & 44 & 4.33 & 0.48 & & & & & & \\
\hline Total & 563 & 4.34 & 0.48 & Total & 130.518 & 562 & & & \\
\hline
\end{tabular}

The variance (ANOVA) analysis was conducted in order to compare the means of importance dimension of teachers' beliefs according to age factor (Table 6). As a result of the analysis, it was found that the mean scores of the teachers did not show any significant differences in terms of age $[\mathrm{F}(5.557)=.391 ; \mathrm{p}>.05]$. When the mean scores were examined, it was seen that all of the participants had similar mean scores $(20-25(M=4.35), 26-30$ years $(M=4.37)$, 31-35 years $(M=4.32)$, 36-40 years $(M=4.30), 41-45$ years $(M=4.39)$, 46 years and over teachers $(M=4.33))$ and this means teachers having different ages believe identically about the importance of using technology in the classroom.

Table 7. The analysis of use dimension by age

\begin{tabular}{|l|l|l|l|l|l|l|l|l|l|}
\hline Age & N & Mean & Std. Deviation & Source of Variance & Sum of Squares & df & Mean Square & F & Sig. \\
\hline $20-25$ & 53 & 4.51 & 0.47 & Between Groups & .377 & 5 & .075 & .284 & .922 \\
\hline $26-30$ & 97 & 4.50 & 0.55 & & & & & & \\
\hline $31-35$ & 192 & 4.46 & 0.49 & & & & & & \\
\hline $36-40$ & 127 & 4.47 & 0.51 & Within Groups & 147.698 & 557 & .265 & & \\
\hline $41-45$ & 50 & 4.52 & 0.56 & & & & & & \\
\hline $46+$ & 44 & 4.42 & 0.53 & & & & & & \\
\hline Total & 563 & 4.48 & 0.51 & Total & 148.075 & 562 & & & \\
\hline
\end{tabular}

The variance (ANOVA) analysis was implemented in order to compare the average of use dimension of teachers' beliefs by age factor. As seen in Table 7, it was found that the average of teachers' use dimension did not show significant difference according to age $[F(5.557)$ $=.284 ; \mathrm{p}>.05]$. When the mean scores were examined, it was found that the teachers 
between the ages of 20-25 $(M=4.51), 26-30$ years $(M=4.50), 31-35$ years $(M=4.46), 36-40$ years $(M=4.47), 41-45$ years $(M=4.52), 46$ years and older teachers $(M=4.42)$ had these mean scores. It could be concluded that the age factor has no effect on teachers' beliefs about using digital technology.

Table 8 . The analysis of expertise dimension by age

\begin{tabular}{|l|l|l|l|l|l|l|l|l|l|}
\hline Age & $\mathrm{N}$ & Mean & Std. Deviation & Source of Variance & Sum of Squares & df & Mean Square & F & Sig. \\
\hline $20-25$ & 53 & 4.06 & 0.41 & Between Groups & 1.663 & 5 & .333 & 1.296 & .264 \\
\hline $26-30$ & 97 & 4.14 & 0.47 & & & & & & \\
\hline $31-35$ & 192 & 4.00 & 0.54 & & & & & & \\
\hline $36-40$ & 127 & 4.09 & 0.49 & Within Groups & 142.938 & 557 & .257 & & \\
\hline $41-45$ & 50 & 4.06 & 0.50 & & & & & & \\
\hline $46+$ & 44 & 3.99 & 0.58 & & & & & & \\
\hline Total & 563 & 4.05 & 0.51 & Total & 144.601 & 562 & & & \\
\hline
\end{tabular}

The variance (ANOVA) analysis was used in order to compare the mean of teachers' expertise dimension by age. The results showed that there was no significant difference between the expertise dimension and age factor $[\mathrm{F}(5.557)=1,296 ; \mathrm{p}>.05]$. These are the mean scores of age ranges: between the ages of 20-25 $(M=4.06), 26-30$ years $(M=4.14)$, 31-35 years $(M=4.00), 36-40$ years $(M=4.09), 41-45$ years $(M=4.06), 46$ years and older teachers $(M=3.99)$. It could be said that teachers' beliefs about expertise were not influenced by the age factor.

Table 9. The analysis of context dimension by age

\begin{tabular}{|l|l|l|l|l|l|l|l|l|l|}
\hline Age & N & Mean & Std. Deviation & Source of Variance & Sum of Squares & df & Mean Square & F & Sig. \\
\hline $20-25$ & 53 & 3.65 & 0.93 & Between Groups & 4.027 & 5 & .805 & 1.209 & .303 \\
\hline $26-30$ & 97 & 3.73 & 0.81 & & & & & & \\
\hline $31-35$ & 192 & 3.65 & 0.80 & & & & & & \\
\hline $36-40$ & 127 & 3.87 & 0.77 & Within Groups & 371.047 & 557 & .666 & & \\
\hline $41-45$ & 50 & 3.78 & 0.82 & & & & & & \\
\hline $46+$ & 44 & 3.78 & 0.86 & & & & & & \\
\hline Total & 563 & 3.74 & 0.82 & Total & 375.074 & 562 & & & \\
\hline
\end{tabular}

The variance (ANOVA) analysis was implemented in order to compare the mean of teachers' context dimension by age. Table 9 shows that there is no statistically significant difference 
between context and age factor $[\mathrm{F}(5.557)=1.209 ; \mathrm{p}>.05]$. The age ranges and mean scores are as following: teachers between 20-25 years $(M=3.65), 26-30$ years $(M=3.73), 31-35$ years $(M=3.65), 36-40$ years $(M=3.87), 41-45$ years $(M=3.78)$, and 46 years and over teachers $(M=3.78)$. It could be said that the age factor has no impact on teachers' beliefs about context.

\subsubsection{Level of Education}

Table 10. The analysis of importance dimension by education level

\begin{tabular}{|l|l|l|l|l|l|l|l|l|l|l|}
\hline Level of education & N & Mean & $\begin{array}{l}\text { Std. } \\
\text { Deviation }\end{array}$ & $\begin{array}{l}\text { Source of } \\
\text { Variance }\end{array}$ & $\begin{array}{l}\text { Sum of } \\
\text { Squares }\end{array}$ & df & $\begin{array}{l}\text { Mean } \\
\text { Square }\end{array}$ & F & Sig. & $\begin{array}{l}\text { Significant difference } \\
\text { (Scheffe) }\end{array}$ \\
\hline Bachelor & 419 & 4.37 & 0.49 & Between Groups & 1.665 & 2 & .832 & 3.617 & .027 & Bachelor-MA Degree \\
\hline MA Degree & 76 & 4.23 & 0.48 & Within Groups & 128.853 & 560 & .230 & & & \\
\hline PhD & 68 & 4.27 & 0.44 & & & & & & & \\
\hline Total & 563 & 4.34 & 0.48 & Total & 130.518 & 562 & & & & \\
\hline
\end{tabular}

In order to compare the means of teachers' importance dimension with regard to their educational level, ANOVA analysis was performed. The analysis of the results showed that the mean scores of the teachers about the importance dimension differed significantly according to education level factor $[\mathrm{F}(2.560)=3.617 ; \mathrm{p}<.05]$. Scheffe test was performed to determine which groups had a significant difference. It was found (see Table 10) that the teachers who had bachelor degree $(M=4.37)$ had a significantly higher mean score than the teachers who had master's degree $(M=4.23)$ while $\mathrm{PhD}$ degree teachers had $(M=4.27)$. The findings indicate that undergraduate level teachers have more positive beliefs about the importance of using digital technology.

Table 11. The analysis of use dimension by education level

\begin{tabular}{|l|l|l|l|l|l|l|l|l|l|l|}
\hline Level of education & N & Mean & $\begin{array}{l}\text { Std. } \\
\text { Deviation }\end{array}$ & $\begin{array}{l}\text { Source of } \\
\text { Variance }\end{array}$ & $\begin{array}{l}\text { Sum of } \\
\text { Squares }\end{array}$ & df & $\begin{array}{l}\text { Mean } \\
\text { Square }\end{array}$ & F & Sig. & $\begin{array}{l}\text { Significant difference } \\
\text { (Scheffe) }\end{array}$ \\
\hline Bachelor & 419 & 4.48 & 0.52 & Between Groups & .531 & 2 & .266 & 1.008 & .365 & \\
\hline MA Degree & 76 & 4.40 & 0.54 & Within Groups & 147.543 & 560 & .263 & & & - \\
\hline PhD & 68 & 4.52 & 0.40 & & & & & & & \\
\hline Total & 563 & 4.48 & 0.51 & Total & 148.075 & 562 & & & & \\
\hline
\end{tabular}

The variance (ANOVA) analysis was performed in order to compare the mean scores of teachers' use dimension in terms of their educational level. The analysis of the results indicated that there was no significant difference between the use dimension and level of 
education factor $[\mathrm{F}(2.560)=1.008 ; \mathrm{p}>.05]$. As seen in Table 11, they had similar mean scores (undergraduate $(M=4.48)$, master $(M=4.40)$, and doctoral graduate teachers $(M=$ 4.52).

Table 12. The analysis of expertise dimension by education level

\begin{tabular}{|l|l|l|l|l|l|l|l|l|l|l|}
\hline Level of education & $\mathrm{N}$ & Mean & $\begin{array}{l}\text { Std. } \\
\text { Deviation }\end{array}$ & $\begin{array}{l}\text { Source of } \\
\text { Variance }\end{array}$ & $\begin{array}{l}\text { Sum of } \\
\text { Squares }\end{array}$ & df & $\begin{array}{l}\text { Mean } \\
\text { Square }\end{array}$ & F & Sig. & $\begin{array}{l}\text { Significant difference } \\
\text { (Scheffe) }\end{array}$ \\
\hline Bachelor & 419 & 4.05 & .51 & Between Groups & .089 & 2 & .044 & .172 & .842 & \\
\hline MA Degree & 76 & 4.08 & .46 & Within Groups & 144.513 & 560 & .258 & & & \\
\hline PhD & 68 & 4.03 & .47 & & & & & & & \\
\hline Total & 563 & 4.05 & .50 & Total & 144.601 & 562 & & & & \\
\hline
\end{tabular}

The variance (ANOVA) analysis was conducted in order to compare the mean scores of teachers' expertise dimension according to their educational background. It was found that the mean scores of teachers' expertise dimension did not show any significant difference according to education level factor $[\mathrm{F}(2.560)=.172 ; \mathrm{p}>.05]$. The mean scores of the teachers are as following (Table 12$)$ : the undergraduate $(M=4.05)$, master $(M=4.08)$ and doctoral degree teachers $(M=4.03)$.

Table 13. The analysis of context dimension by education level

\begin{tabular}{|l|l|l|l|l|l|l|l|l|l|l|}
\hline Level of education & N & Mean & $\begin{array}{l}\text { Std. } \\
\text { Deviation }\end{array}$ & $\begin{array}{l}\text { Source of } \\
\text { Variance }\end{array}$ & $\begin{array}{l}\text { Sum of } \\
\text { Squares }\end{array}$ & df & $\begin{array}{l}\text { Mean } \\
\text { Square }\end{array}$ & F & Sig. & $\begin{array}{l}\text { Significant difference } \\
\text { (Scheffe) }\end{array}$ \\
\hline Bachelor & 419 & 3.69 & 0.81 & Between Groups & 3.954 & 2 & 1.977 & 2.983 & .051 & \\
\hline MA Degree & 76 & 3.82 & 0.78 & Within Groups & 371.120 & 560 & .663 & & & \\
\hline PhD & 68 & 3.93 & 0.85 & & & & & & & \\
\hline Total & 563 & 3.74 & 0.82 & Total & 375.074 & 562 & & & & \\
\hline
\end{tabular}

The variance (ANOVA) analysis was performed in order to compare the mean scores of teachers' context dimension according to their level of education. As seen in Table 13, it was found that the context dimension of the teachers did not show significant difference according to level of education factor $[\mathrm{F}(2.560)=.172 ; \mathrm{p}>.05]$. The mean scores of the teachers are as follows (Table 13): the undergraduate $(M=3.69)$, master $(M=3.82)$ and doctoral graduate teachers $(M=43.93)$. 


\subsubsection{Years of Teaching Experience}

Table 14. The analysis of importance dimension by teaching experience

\begin{tabular}{|l|l|l|l|l|l|l|l|l|l|l|}
\hline Teaching experience & $\mathrm{N}$ & Mean & $\begin{array}{l}\text { Std. } \\
\text { Deviation }\end{array}$ & $\begin{array}{l}\text { Source of } \\
\text { Variance }\end{array}$ & $\begin{array}{l}\text { Sum of } \\
\text { Squares }\end{array}$ & df & $\begin{array}{l}\text { Mean } \\
\text { Square }\end{array}$ & F & Sig. & $\begin{array}{l}\text { Significant difference } \\
\text { (Scheffe) }\end{array}$ \\
\hline $1-5$ & 116 & 4.35 & 0.46 & Between Groups & .697 & 4 & .174 & .749 & .559 & \\
\hline $6-10$ & 152 & 4.37 & 0.50 & & & & & & & \\
\hline $11-15$ & 164 & 4.30 & 0.48 & & & & & & & - \\
\hline $16-20$ & 80 & 4.30 & 0.48 & Within Groups & 129.821 & 558 & .233 & & & \\
\hline $21+$ & 51 & 4.37 & 0.50 & & & & & & & \\
\hline Total & 563 & 4.34 & 0.48 & Total & 130.518 & 562 & & & & \\
\hline
\end{tabular}

The variance (ANOVA) analysis was carried out to compare the importance dimension and their years of teaching experience. As seen in Table 14, it was found that there was no significant difference between the mean scores of teachers' importance dimension and years of teaching experience $[\mathrm{F}(4.558)=.749 ; \mathrm{p}>.05]$, (teachers having experience between 1-5 years $(X=4.35), 6-10$ years $(X=4.37), 11-15$ years $(X=4.30), 16-20$ years $(X=4.30)$, teachers with experience of 21 years and over $(X=4.37))$. In this context, it can be said that teaching experience does not have a significant effect on the teachers' beliefs about the importance of using digital technology.

Table 15. The analysis of use dimension by teaching experience

\begin{tabular}{|l|l|l|l|l|l|l|l|l|l|l|}
\hline $\begin{array}{l}\text { Teaching } \\
\text { Experience }\end{array}$ & N & Mean & $\begin{array}{l}\text { Std. } \\
\text { Deviation }\end{array}$ & $\begin{array}{l}\text { Source of } \\
\text { Variance }\end{array}$ & $\begin{array}{l}\text { Sum of } \\
\text { Squares }\end{array}$ & df & $\begin{array}{l}\text { Mean } \\
\text { Square }\end{array}$ & F & Sig. & $\begin{array}{l}\text { Significant difference } \\
\text { (Scheffe) }\end{array}$ \\
\hline $1-5$ & 116 & 4.47 & 0.52 & Between Groups & .274 & 4 & .068 & .258 & .904 & \\
\hline $6-10$ & 152 & 4.51 & 0.48 & & & & & & & \\
\hline $11-15$ & 164 & 4.47 & 0.50 & & & & & & & - \\
\hline $16-20$ & 80 & 4.45 & 0.58 & Within Groups & 147.801 & 558 & .265 & & & \\
\hline $21+$ & 51 & 4.49 & 0.52 & & & & & & & \\
\hline Total & 563 & 4.48 & 0.51 & Total & 148.075 & 562 & & & & \\
\hline
\end{tabular}

In addition, in order to compare the average of teachers' use dimension according to teaching experience, the variance (ANOVA) analysis was performed. As a result of the analysis, it was found that there was no significant difference between the mean scores of teachers' use dimension between the years of teaching experience $[\mathrm{F}(4.558)=.258 ; \mathrm{p}>.05]$, (teachers having experience between $1-5$ years $(X=4.47), 6-10$ years $(X=4.51), 11-15$ years $(X=$ 
$4.47), 16-20$ years $(X=4.45)$, teachers with seniority of 21 years and over $(X=4.49))$. In this context, it can be said that teaching experience does not have a significant effect on teachers' beliefs about using digital technology.

Table 16. The analysis of expertise dimension by teaching experience

\begin{tabular}{|l|l|l|l|l|l|l|l|l|l|l|}
\hline $\begin{array}{l}\text { Teaching } \\
\text { experience }\end{array}$ & N & Mean & $\begin{array}{l}\text { Std. } \\
\text { Deviation }\end{array}$ & $\begin{array}{l}\text { Source of } \\
\text { Variance }\end{array}$ & $\begin{array}{l}\text { Sum of } \\
\text { Squares }\end{array}$ & df & $\begin{array}{l}\text { Mean } \\
\text { Square }\end{array}$ & F & Sig. & $\begin{array}{l}\text { Significant difference } \\
\text { (Scheffe) }\end{array}$ \\
\hline $1-5$ & 116 & 4.09 & 0.44 & Between Groups & .408 & 4 & .102 & .395 & .812 & \\
\hline $6-10$ & 152 & 4.08 & 0.49 & & & & & & & \\
\hline $11-15$ & 164 & 4.02 & 0.55 & & & & & & & - \\
\hline $16-20$ & 80 & 4.04 & 0.47 & Within Groups & 144.193 & 558 & .258 & & & \\
\hline $21+$ & 51 & 4.03 & 0.62 & & & & & & & \\
\hline Total & 563 & 4.05 & 0.51 & Total & 144.601 & 562 & & & & \\
\hline
\end{tabular}

In order to compare the average of teachers' expertise dimension according to teaching experience, the variance (ANOVA) analysis was performed. When the results were analyzed in Table 16, it was found that there was no significant difference between teachers' expertise dimension and years of teaching experience $[\mathrm{F}(4.558)=.395 ; \mathrm{p}>.05]$, (teachers having experience between $1-5$ years $(X=4.09), 6-10$ years $(X=4.08), 11-15$ years $(X=4.02)$, $16-20$ years $(X=4.04), 21$ years and over seniority teachers $(X=4.03))$. In this context, it can be said that teaching experience does not have a significant effect on the beliefs of teachers about the expertise in using digital technology.

Table 17. The analysis of context dimension by teaching experience

\begin{tabular}{|l|l|l|l|l|l|l|l|l|l|l|}
\hline $\begin{array}{l}\text { Teaching } \\
\text { Experience }\end{array}$ & N & Mean & $\begin{array}{l}\text { Std. } \\
\text { Deviation }\end{array}$ & $\begin{array}{l}\text { Source of } \\
\text { Variance }\end{array}$ & $\begin{array}{l}\text { Sum of } \\
\text { Squares }\end{array}$ & df & $\begin{array}{l}\text { Mean } \\
\text { Square }\end{array}$ & F & Sig. & $\begin{array}{l}\text { Significant difference } \\
\text { (Scheffe) }\end{array}$ \\
\hline $1-5$ & 116 & 3.71 & 0.87 & Between Groups & .626 & 4 & .157 & .233 & .920 & \\
\hline $6-10$ & 152 & 3.74 & 0.75 & & & & & & & \\
\hline $11-15$ & 164 & 3.73 & 0.83 & & & & & & & - \\
\hline $16-20$ & 80 & 3.71 & 0.85 & Within Groups & 374.448 & 558 & .671 & & & \\
\hline $21+$ & 51 & 3.84 & 0.80 & & & & & & & \\
\hline Total & 563 & 3.74 & 0.82 & Total & 375.074 & 562 & & & & \\
\hline
\end{tabular}

The variance (ANOVA) analysis was conducted in order to compare the averages of the teachers regarding the context dimension and their teaching experience. Table 17 indicated that there was no significant difference between teachers' context dimension and years of 
teaching experience $[\mathrm{F}(4.558)=.233 ; \mathrm{p}>.05]$, (teachers having experience between $1-5$ years $(X=3.71), 6-10$ years $(X=3.74), 11-15$ years $(X=3.73), 16-20$ years $(X=3.71)$, teachers with experience of 21 years and over $(X=3.84)$. In this context, it can be said that teaching experience does not have a significant effect on the beliefs of teachers about the context in using digital technology.

\subsubsection{Technology Training}

Table 18. Have you ever learned how to use digital technology in the classroom such as workshop, conference, or formal course?

\begin{tabular}{|l|l|l|}
\hline & Frequency & Percent \\
\hline Yes & 294 & 52.2 \\
\hline No & 269 & 47.8 \\
\hline Total & 563 & 100.0 \\
\hline
\end{tabular}

When Table 18 is examined, it is seen $52.2 \%$ (294) of the students stated that they have attended various courses about the use of digital technology in the classroom and $47.8 \%$ (269) of them did not.

Table 19. Comparison of teachers' beliefs about digital technology according to their participation in the course

\begin{tabular}{|l|l|l|l|l|l|l|l|}
\hline Sub dimensions & Attendance to a course & $\mathrm{N}$ & Mean & Std. Deviation & $\mathrm{t}$ & $\mathrm{df}$ & $\mathrm{Sig}$. \\
\hline \multirow{3}{*}{ Importance } & Yes & 294 & 4.3616 & .48088 & 1.314 & 561 & .189 \\
\cline { 2 - 9 } & No & 269 & 4.3082 & .48238 & & & \\
\hline \multirow{3}{*}{ Use } & Yes & 294 & 4.5145 & .52619 & 1.818 & 561 & .070 \\
\cline { 2 - 9 } & No & 269 & 4.4359 & .49656 & & & \\
\hline \multirow{3}{*}{ Expertise } & Yes & 294 & 4.1153 & .52037 & 2.984 & 561 & .003 \\
\cline { 2 - 9 } & No & 269 & 3.9884 & .48485 & & & \\
\hline \multirow{3}{*}{ Context } & Yes & 294 & 3.8312 & .77121 & 2.917 & 561 & .004 \\
\cline { 2 - 9 } & No & 269 & 3.6315 & .85346 & & & \\
\hline
\end{tabular}

T-test was used in order to compare teachers' beliefs about digital technology according to their participation in the course. The results in Table 19 showed that there was no significant difference between dimensions of importance $\mathrm{t}(1.314)=.189, \mathrm{p}>.05$ and use $\mathrm{t}(1.818)=.07$, $\mathrm{p}>.05$. However, in the dimension of expertise $\mathrm{t}(2.984)=.003, \mathrm{p}<.05$, and in the context dimension $\mathrm{t}(2.917)=.004, \mathrm{p}<.05$, it was found that there was a significant difference 
between the teachers who participated in a course and who did not attend a course on using digital technology. When the averages are examined, teachers perceive themselves to be more competent in the use of digital technology than the teachers who participated in the course (X $=4.11)$ than those who did not $(X=3.98)$. Similarly, when the averages of context were examined, the teachers who participated in a course $(\mathrm{X}=3.83)$ evaluated the contextual conditions more positively than the non-participants $(\mathrm{X}=3.63)$.

\section{Discussion}

The present study investigated Turkish EFL teachers' beliefs about implementing digital technology in teaching English and the factors affecting those beliefs. The results indicated that teachers shared positive views on the use of digital technology in the EFL classroom in terms of importance, use, expertise, and context. From the factors; gender, age and teaching experience did not create any significant change on teachers' beliefs. However, it was seen that the teachers who had technology-related training about the use of digital technology have more positive beliefs than the teachers who did not attend. Additionally, it was somewhat surprising that the teachers having bachelor's degree consider using digital technology in the classroom as more significant than the teachers who had master's degree.

This study produced results which corroborate the findings of a great deal of the previous work in this field. When compared to Lam's (2000) study, the findings of the current study supports his research except technology-related training. He found that the background features of the L2 teachers such as the number of teaching experience years, prior technological training, gender or age had no impact on teachers' technology use in language teaching.

The findings of the present study slightly confirmed with those of Karakaya's (2010) study which showed that while age and gender had no significant effect on teachers' attitudes about using technology, the degrees teachers hold and teaching experience showed strong positive correlation with the attitudes toward using ICT. Similarly, both this present study and Yunus's (2007) study revealed that teachers had positive views on implementing digital technology in language teaching. However, Yunus (2007) ascertained that ICT was not generally utilized by Malaysian ESL teachers and the underlying causes were basically associated with unavailability/lack of access and lack of training. At this point, a similar conclusion was reached by Sağlam and Sert's (2012) study which highlighted the need of teachers and students being lack of confidence and skills in utilizing technology for ICT training in ELT.

Additionally, positive effect of technology-related training on the beliefs in this study seems to be consistent with Yang \& Huang's (2007) study and Chung's (2014) study which found positive correlation between technology-mediated teaching activities and technological training.

However, the present study's findings differ from Rahimi and Yadollahi's (2011) findings which found inverse correlation between ICT use and teachers' age, years of teaching experience and computer anxiety.

Teachers, with all other members of every modern society, move to "how" along with "what". 
We are aware that technology makes teaching both more "flexible" and "student-centered" by considering and touching multiple intelligences and interests. Especially, when the pandemic (Covid-19) shifts the traditional teaching into a technology based teaching/learning and designs the trends in the field of education, the beliefs of teachers on technology-based teaching is of vital importance. Keeping this in mind, it is important to try to find out the beliefs of Turkish EFL teachers about implementing digital technology by including different variables in the classroom and the underlying factors which affect their beliefs as this will certainly contribute the field and help curriculum designers governmental authorities and academics to work together and set up strategies to help both pre-service and in-service EFL teachers design the present-day foreign language teaching classrooms in Turkey especially when we strongly need to be creative and innovative in designing technology-driven lecture plans and delivering technology-based methodology in EFL settings in Turkish educational context in which there are nearly eight million students, the number more than many countries in Europe.

\subsection{Educational Implications}

These findings may help us to understand what Turkish EFL teachers believe about implementing digital technology and the factors behind those beliefs. These results provide further support for the hypothesis that Turkish EFL teachers have positive views about using digital technology and technology-related training changes the beliefs on digital technology. The study could yield findings for teachers, researchers and governmental organizations. One of the issues that emerges from these findings is technology-related training should be obligatory for the teachers, governmental organizations should support EFL teachers in terms of integrating technology into EFL classrooms. Teachers can also be supplied in-service trainings to improve their technology-adapted teaching.

\subsection{Suggestions for Further Research}

The present study presents an overview on the beliefs of Turkish EFL teachers about implementing digital technology in the classroom and the underlying factors which affect their beliefs. A deeper and further research can be conducted to find out the more specific and detailed technology usage in an EFL classroom and the most common used apps, websites EFL teachers mostly prefer to use in the classroom may yield more specific findings in language teaching.

\section{References}

Almekhlafi, A. G., \& Almeqdadi, F. A. (2010). Teachers' Perceptions of Technology Integration in the United Arab Emirates School Classrooms (Vol. 13, pp. 165-175).

Başal, A. (2015). English language teachers and technology education.

Chaaban, Y., \& Ellili-Cherif, M. (2017). Technology integration in EFL classrooms: A study of Qatari independent schools. Education and Information Technologies, 22(5), 2433-2454. https://doi.org/10.1007/s10639-016-9552-3

Chung, S. (2014). Pre-Service and In-Service ESL Teachers' Beliefs About the Use of Digital 
Technology in the Classroom (Doctoral dissertation, Carleton University).

Creswell, J. W. (2002). Educational research: Planning, conducting, and evaluating quantitative (pp. 146-166). Upper Saddle River, NJ: Prentice Hall.

Ding, A. C. E., Ottenbreit-Leftwich, A., Lu, Y. H., \& Glazewski, K. (2019). EFL teachers' pedagogical beliefs and practices with regard to using technology. Journal of Digital Learning in Teacher Education, 35(1), 20-39. https://doi.org/10.1080/21532974.2018. 1537816

Fauzi, A., Damayanti, D., \& Ilahi, T. (2017). A Teacher'S Beliefs on the Integration of Video Technology in Teaching Speaking: A Case Study. IJPTE : International Journal of Pedagogy and Teacher Education, 1(1), 46-54. https://doi.org/10.20961/ijpte.v1i1.4914

Galvis, H. A. (2012). Understanding Beliefs, Teachers' Beliefs and Their Impact on the Use of Computer Technology. Profile Issues in Teachers' Professional Development, 14(2), 95-112.

Judson, E. (2006). How Teachers Integrate Technology and Their Beliefs About Learning: Is There a Connection? Journal of Technology and Teacher Education, 14(3), 581-597.

Kagan, D. M. (1992). Implication of research on teacher belief. Educational Psychologist, 27(1), 65-90. https://doi.org/10.1207/s15326985ep2701_6

Karakaya, K. (2010). An investigation of English language teachers' attitudes toward computer technology and their use of technology in language teaching (Unpublished Master's Thesis, Middle East Technical University, Graduate School of Social Sciences, Ankara).

Lam, Y. (2000). Technophilia vs. technophobia: A preliminary look at why second-language teachers do or do not use technology in their classrooms. Canadian Modern Language Review, 56(3). https://doi.org/10.3138/cmlr.56.3.389

Lin, L. L. (2009). Technology and Second Language Learning.

Liu, H., Lin, C. H., \& Zhang, D. (2017). Pedagogical beliefs and attitudes toward information and communication technology: A survey of teachers of English as a foreign language in China. Computer Assisted Language Learning, 30(8), 745-765. https://doi.org/10.1080/ 09588221.2017 .1347572

Mirzajani, H., Mahmud, R., Ayub, A. F. M., \& Wong, S. L. (2016). Teachers' acceptance of ICT and its integration in the classroom. Quality Assurance in Education, 24(1). https://doi.org/10.1108/QAE-06-2014-0025

Murthy, K. D. (2020). Paradigm Shift: A Need of the Hour in the Techno Era. Borneo Journal of Medical Sciences.

Pajares, M. F. (1992). Teachers' beliefs and educational research: Cleaning up a messy construct. Review of Educational Research, 62(3), 307-332. https://doi.org/10.3102/00346 543062003307 
Phipps, S., \& Borg, S. (2009). Exploring tensions between teachers' grammar teaching beliefs and practices. System, 37(3), 380-390. https://doi.org/10.1016/j.system.2009.03.002

Prensky, M. (2001). Digital natives, digital immigrants. On the Horizon, 9(5). https://doi.org/10.1108/10748120110424816

Rahimi, M., \& Yadollahi, S. (2011). ICT Use in EFL Classes: A Focus on EFL Teachers' Characteristics. World Journal of English Language, 1(2), 17-29. https://doi.org/10.5430/ wjel.v1n2p17

Saglam, A. L. G., \& Sert, S. (2012). Perceptions of In-Service Teachers Regarding Technology Integrated English Language Teaching. Turkish Online Journal of Qualitative Inquiry, 3(3), 1-14. https://doi.org/10.17569/tojqi.55006

Shiel, G., \& Cartwright, F. (2015). National Assessments of Educational Achievement, Volume 4: Analyzing Data from a National Assessment of Educational Achievement. The World Bank. https://doi.org/10.1596/978-0-8213-9583-7

Tondeur, J., Van Braak, J., Ertmer, P. A., \& Ottenbreit-Leftwich, A. (2017).Understanding the relationship between teachers' pedagogical beliefs and technology use in education: A systematic review of qualitative evidence. Educational Technology Research and Development, 65(3), 555-575. https://doi.org/10.1007/s11423-016-9481-2

Uluay, G., Çalışkaner Nibat, G., \& Arıkan, N. (2019). Öğretmen Adaylarının Teknoloji Entegrasyonuna Yönelik İnançları: Teknoloji Uyarlamaları Uygulama Ölçeğinin Türkçeye Uyarlanmas1. Kastamonu Ĕ̆itim Dergisi, 27(4), 1529-1540. https://doi.org/10.24106/ kefdergi.3124

Yang, S. C., \& Huang, Y. F. (2008). A study of high school English teachers' behavior, concerns and beliefs in integrating information technology into English instruction. Computers in Human Behavior, 24(3), 1085-1103. https://doi.org/10.1016/j.chb.2007.03.009

Yunus, M. M. (2007). Malaysian ESL teachers' use of ICT in their classrooms: Expectations and realities. ReCALL, 19(1), 79-95. https://doi.org/10.1017/S0958344007000614

Zengin, Ö., \& Aksu, M. (2017). A Review Study on the Integration of Technology into Foreign Language Education in Turkey. Journal of Faculty of Educational Sciences, 50(2).

\section{Copyright Disclaimer}

Copyright for this article is retained by the author(s), with first publication rights granted to the journal.

This is an open-access article distributed under the terms and conditions of the Creative Commons Attribution license (http://creativecommons.org/licenses/by/3.0/). 